\title{
A TEHERSZÁLLÍTÁSI LOGISZTIKA FENNTARTHATÓSÁGI VETÜLETEI ÉS EZEK ALAPVETŐ KOCKÁZATAI AZ ELKÖVETKEZENDŐ ÉVEKRE VONATKOZÓAN
}

\author{
Nagy Sándor
}

\begin{abstract}
Absztrakt: A fenntarthatósági kérdések minden egyes ágazat és szektor szempontjából komoly kihívások elé állítják a döntéshozókat, illetve azokat a szereplöket, akiknek valamilyen közvetlen ráhatása van a folyamatok alakulására. Ezeknek a kérdéseknek a megfogalmazása rendkívül fontos és idöszerü; a megfelelö, intelligens megválaszolásuk ugyanakkor hozzájárulhat a globális rendszerek fenntarthatóságához is. Intelligens válaszokon azokat a reakciókat értem, amelyek a korábbi megoldásokhoz hasonlóan versenyképességi elönyöket generálnak az ágazat érintettjeinek. A tanulmány célkitüzése, hogy a választott területre vonatkozóan beazonosítsa a legfontosabb megoldásra váró problémákat, azokat rendszerezöen ismertesse, valamint a velük kapcsolatos kockázatokra is rámutasson.

Abstract: Sustainability issues are a serious challenge for decision-makers and actors who have a direct influence on the evolution of processes for each sector and branch. The formulation of these questions is extremely important and timely; their proper, intelligent response can also contribute to the sustainability of global systems. Under intelligent responses I mean those reactions, which, similar to previous solutions, generate competitive advantages for stakeholders in the sector. The objective of the study is to identify the most relevant problems to be solved for the chosen research area, to present them in a systematic way and to point out the risks associated with them.
\end{abstract}

Kulcsszavak: logisztika, áruszállítás, teherszállítás, fenntarthatóság, logisztikai kihívások

Keywords: logistics, freight transport, sustainability, challenges of logistics

\section{Bevezetés}

Korunk társadalmi-gazdasági folyamataiban, a megtermelt javak és szolgáltatások elosztásában, illetve újraelosztásában meghatározó szerepe van a logisztikai folyamatoknak. Ugyanakkor a társadalmak és a gazdasági rendszerek kizárólag a természeti környezettel összefonódva, abba integrálva értelmezhetőek. Ezeket a nyitott rendszereket alkotóelemeik, valamint a szereplők közötti dinamikus kapcsolatok révén kialakuló struktúrákkal jellemezhetjük. Az ilyen rendszerek nemlineárisak és a megfelelő visszacsatolási folyamatok megléte esetén adaptívnak tekinthetőek. Azonban az eddig felsoroltaknál sokkal több meghatározó attribútummal kell rendelkezniük az egzakt beazonosításhoz. Ezek közül a téma szempontjából az alábbiak a legfontosabbak - kiegészítve és pontosítva a fentieket: (1) adaptív nyomáskényszer, amely a szereplőket, ágenseket valamilyen cselekvésre, válaszreakciókra késztetik; (2) rendszerdinamika - azaz a lokális szinten megjelenő interakciókból kialakuló makroszintü, rendszerszintü mintázatok megjelenése. (3) Ezek az interakciók, szubjektív döntések egyszerü alapelvek mentén történnek (önszervezödés, önérdekkövetés), amely a rendszerdinamikai folyamatok beindulásához vezetnek. (4) A holisztikus és a hosszú távú szemlélet hiánya (az egyén szemszögéből vizsgálódva a rendszer gyakran „beláthatatlan”), hiszen (5) az ilyen rendszerek több szintből épülhetnek fel (integráltság) és több vetület mentén is vizsgálhatóak. (6) A rendszerek jövőbeni viselkedésének elörejelzése nem 
lehetséges; (7) a rendszer méretéhez vagy egyéb jellemzőéhez mérten elenyészö inputváltozás is extrém változásokat idézhet elő makroszinten (nemlineáris viselkedés) (Nagy-Gulyás, 2015).

A világot lefedő áruszállítási* rendszerek is hordozzák magukon a nemlineáris jegyeket (*a továbbiakban az áruszállítást és a teherszállitást szinonimaként kezelem annak ellenére is, hogy tartalmukban árnyalatnyi különbségek vannak). A gazdasági szereplök, a töketulajdonosok ugyanakkor igyekeznek lineáris folyamatokat kiépíteni (szerződések, INCOTERMS szokványok használata, biztosítások, ellenügyletek stb.), hiszen azok inkább kiszámíthatóak, előre tervezhetőek, és a tőke szabályozott, kiszámítható kockázati szintü reprodukciójához leginkább ezek a feltételek, körülmények járulnak hozzá - legalábbis a hagyományos szemlélet szerint. Mivel az áruszállítás számos más, magasabb szintü rendszert szolgál ki (sokszor azok metszetében, metszeteiben helyezkedik el) és mélyreható kapcsolatokban áll azokkal, ezért jelentősége és a nemlineáris folyamatok alapján kialakuló makroszintü mintázatokhoz való hozzájárulása és szerepe megkérdőjelezhetetlen.

Amennyiben az áruszállítási logisztika fenntarthatóságról beszélünk - vagy akár annak hozzájárulásáról más, magasabb szintü rendszerek fenntarthatóságához -, akkor a fenti jellemzöket mindenképp figyelembe kell vennünk.

\section{Tendenciák és provokatív kérdések a fenntarthatóságról}

Az teherszállítás egy olyan tevékenységsorozat, amely mind a belső (üzemen belüli), mind a külsö (üzemen kívüli) logisztikai folyamatokra kiterjed, valamint azokon átívelve az értékesítés utáni szolgáltatások kapcsán is megjelenhet. Ugyanakkor, az értéklánc elemei különböző módokon érinthetik és befolyásolhatják a szállítási tevékenységek mértékét és minőségét.

Általánosságban elmondható, hogy a piaci célterületek kiterjedése (földrajzi értelemben is), a szélesebb beszállítói kör és a konzekvensen növekvő szállítási utak hozzájárultak ahhoz, hogy nagyobb függőség alakuljon ki a szállítási és a hozzá kapcsolódó tevékenységektöl (McKinnon, 2003; Golicic et al., 2010).

$\mathrm{Az}$ Európai Unió gazdaságának is szüksége van eredményes és hatékonyan müködő logisztikai rendszerre, amely a fenntarthatóság kritériumainak is megfelel. A logisztika számos területre kiterjed, de a teherszállítási iparág az egyik legjelentősebb és a legkevésbé környezetkímélő, arányaiban messze ez a legszennyezöbb (European Commission, 2015; University of Leeds-European Parliament, 2010). Az igény keletkezése, a fenntarthatóság fogalmának deklarálása és uniós stratégiai dokumentumokban való szerepeltetése még érthető is, de külön elgondolkodtató kérdés, hogy mit is jelent valójában a fenntarthatóság, illetve ebben a kontextusban, hogyan függ és hogyan hat ki más rendszerek fenntarthatóságára és az elméleti megfontolások miként ültethetőek át gyakorlati megvalosításokba. Többe a fenntarthatóság, mint egy gondolati „délibáb”, egy jól eladható hívószó vagy egy mentális lenyomat az elménkben?

A fenntartható áruszállítási logisztika kapcsán - a fogalom jobb megértése érdekében - pár provokatív kérdést akár meg is fogalmazhatunk elözetesen: 
- Szükség van-e ilyen mértékü teherszállítási forgalomra? Mennyire lokalizálható a gyártás vagy a fogyasztás? Mennyire értékelődik fel a lokalizáció a globalizációs folyamatok ámyékában? (3D nyomtatás, ekereskedelem és egyéb innovációk)

- Kinek az érdekét szolgálja alapvetően és meghatározóan a szállítási logisztikai rendszer müködése? (Fogyasztók vagy a tökereprodukcióban érdekelt gyártók?)

- Hogyan értelmezhető az értékteremtés a teherszállítási logisztika folyamataiban, illetve hogyan járulhatnak ezek hozzá egy magasabb szintü rendszer fenntarthatóságához?

- A teherszállítási logisztika vizsgálata milyen magasabb szintü rendszerekben elhelyezve ad objektívebb képet?

- Szükséges-e túllépnünk a klasszikus fenntarthatósági pilléreken (triple bottom line) és a statikus szemléleten, helyettesítve azt egy dinamikus, integrált- és rendszerszemléletü, kiterjesztett értelmezéssel?

A kérdések megválaszolása - ha egyáltalán ez lehetséges - nem képezik részét jelen tanulmánynak, de a válaszok keresése egyre közelebb vihet a megértéshez. Az áruszállítási logisztika fenntarthatóságával kapcsolatos problémák és kihívások megfogalmazása - tehát a kiindulási kondíciók és az uralkodó folyamatok beazonosítása - gyakori és népszerü téma a vonatkozó szakirodalomban. A következő fejezet ezekből állít össze egy releváns válogatást.

\section{A teherszállítási logisztika legfontosabb problémái)}

A szakirodalom alapján a teherszállítási logisztika számos problémával küzd és globális szinten nem a fenntarthatóság irányába tart. Ezek a problémák, kihívások rendkívül összetettek és szerteágazók, hiszen számos más rendszert is érintenek a logisztikai tevékenységek (Kohn-Brodin, 2008; Santén, 2013; University of LeedsEuropean Parliament, 2010).

Ezek közül talán a legmarkánsabb az, hogy eddig nem sikerült különválasztani az áruszállítás és a GDP összefonódó, egymást kiegészítő növekedési tendenciáit és ez ahhoz vezetett, hogy az előbbi ágazat globálisan egyre nagyobb károsanyagkibocsájtóvá vált. Számos jelenleg használt üzleti gyakorlat (pl.: az egyes vállalatok logisztikai stratégiái a decentralizálttól a központosított elosztási rendszerek felé mozdul el) az áruszállítás volumenének tendenciózus növekedéséhez vezet, ezen belül is a közúti árufuvarozás drasztikus felfutásához. Ezzel párhuzamosan a fenntarthatóbbnak nevezett vasúti és vízi szállítás piaci részesedése nem növekszik.

Hiába a sok innováció és előremutató megoldás, az EU-ban a fenntartható módok elterjedését és azok jótékony hatásait sajnos globális szinten ellensúlyozzák a világ más részein tapasztalható ellentétes folyamatok. Söt a közlekedéssel kapcsolatos infrastruktúra létesítése és áteresztő képességének növelése, fenntartása hatalmas költségvonzattal járhat, ennek a (felelős és eredményes közpénzügyi) finanszírozása sem feltétlen megoldott. Ha a fö áramlatok mélyére tekintünk, akkor számos olyan jelenséget azonosít a szakirodalom, amelyek összegződve - a hálózati 
struktúrák, az elemek közötti kapcsolatok és a rendszerdinamika révén - elösegítik a legfontosabb makrofolyamatok fennmaradását és megerősödését (Santén, 2013).

Ilyenek lehetnek a lokálisan koncentrálódó emissziós terhelések, amelyek föleg a városokban és az urbánus területeken jelentkeznek, és együtt járnak a szintén koncentrálódó egészségügyi kockázatokkal. Mindezt kiegészíti, illetve tovább mélyíti a zajterhelés, a torlódások és az ebből fakadó kumulált időveszteségek. A helyi szinten megfigyelhető anomáliák összeadódva és folyamatokat katalizálva direkt és indirekt módon hatnak a globális szinten értelmezhetö fenntarthatóságra. Szintén ide sorolhatóak a gyorsasági, megbízhatósági és egyéb (minőségi) igények növekedése a megrendelők részéről, valamint a szállítást sújtó hatékonysági problémák, illetve a jelentős energiaveszteségek. Probléma, hogy a kereslet és a kínálat összehangolása időben, térben, költségérzékenységben, mennyiségben, minőségben nehezen kivitelezhető. A fenntarthatóság pontos értelmezése és mérése sem megoldott, hiányoznak az egységes indikátorok és az alapos hatásvizsgálatok.

$\mathrm{Az}$ teherszállítás területén - jellegéböl és a mögötte húzódó lobbyérdekek miatt - sokkal nehezebb megvalósítani a fenntarthatóságot, mint a személyszállításban. E mögött számos tényező sorakozik fel, beleértve azt, hogy (1) a sokkal hatékonyabb hajtómüvek kifejlesztése csak hosszú távon lehetséges, (2) azok a faktorok, amelyek a szállítandó áruk természetétől függnek, (3) az olyan szignifikáns tényezőárváltozások, amelyek a szállítási módok közötti váltást, eltolódást vonják maguk után (közút $\rightarrow$ vasút), illetve (4) azon innovációk hiánya, amelyek hozzájárulhatnának a fenntartható szállításhoz (Kohn-Brodin, 2008; Santén, 2013; University of LeedsEuropean Parliament, 2010).

Az összes említett problémát és kihívást tovább gerjeszti az a körülmény, hogy nem megfelelöek a kizöldülésre irányuló ösztönzők, és persze komoly érdekütközések, konfliktusok figyelhetőek meg az elsödleges, rövid távú tőketulajdonosi érdekek, valamint a hagyományos fenntarthatósági pillérek kinyilatkoztatott elképzelései között (társadalmi, gazdasági és környezeti tényezök és ezen metszetek szereplöi).

Az utóbbi területet tárja fel részletesen Santén (2013) egy széles irodalmi bázison nyugvó dolgozatában. Nála már megjelenik a logisztikai rendszer vertikális integráltságának a hangsúlyozása (részletesebben: Santén, 2013 idézi Wandel et al., 1992), a fenntartható logisztika minél egzaktabb körülírásának az igénye, valamint a már említett konfliktushelyzetek elemzö bemutatása. Az integráltság itt alapvetően azt jelenti, hogy a logisztikai rendszereknek értelmezhetö mikro-, mezo- és makroszintje is. Ezek a szintek egymással kapcsolatban vannak és kihatnak egymásra. A legalacsonyabb szinten tevékenykedő entitások müködésének és döntéseinek hatásai a magasabb szintekre is hatással vannak, a rendszerdinamikai folyamatok révén mintázatok jelennek meg. A hatások visszafelé is tetten érhetöek. A magasabb szinteken kialakuló jelenségek, vagy a kialakulásuknak kockázataira adott szabályozási (jogszabályi, ösztönzésbeli, megtervezett kontroll-mechanizmusi vagy egyéb) válaszreakciók befolyásolják az alsóbb szintek müködését, illetve döntési környezetét. 
Hagyományosan - egy adott vállalat szempontjából vizsgálódva - a logisztikai tevékenységeit a profitmaximalizálásnak alávetve végzik, magas szolgáltatási szintre és alacsony költségekre törekedve. A logisztikával foglalkozó szakirodalomban a különböző célkitűzések közötti választás, a közöttük lévő egyensúly optimalizálása jó ismert probléma. Johnson (2008) rávilágít, hogy a fenti, a leginkább jellemző célkitüzések hogyan rivalizálnak egymással az értékteremtési folyamatok különböző összetevői mentén. Vachon és Klassen (2006) az ellátási láncok kizöldülését tárgyalják és megemlítik, hogy a társadalmi, környezeti és gazdasági célkitüzések harmonizálhatóak, de érdekütközések lehetnek közöttük (ahogy az látható is a fenntarthatatlan trendek kapcsán a szállítási ágazatban).

Ugyanakkor a természeti és társadalmi kérdéseket nem részesítik elönyben a vizsgált cégeknél. Vachon és Klassen megállapítják, hogy „valószinütlen az, hogy a környezeti vonatkozású célkitüzések és ügyek elsöbbséget élveznének az alapvetö müködési teljesítményt meghatározó tényezökkel szemben, mint például a költségek, a minöség és a szállítás" (Vachon-Klassen, 2006: 801). Rodrigue és munkatársai (2001) a költségek, az idő és rugalmasság, a logisztikai hálózat, a megbízhatóság és a raktározás területeit azonosították be, ahol a zöld logisztika kapcsán érdekütközések megjelenhetnek.

Santén (2013) érvelésének a következő a lényege: annak ellenére, hogy az egész logisztikai szektor hozzájárul a társadalmi jóléthez és a gazdasági fejlödéshez a szolgáltatásai és funkcióellátásai révén (makroszint) (például: javak széles körének elérhetösége a társadalom számára), a mikrokörnyezetben a gazdasági önérdekek és az érdekérvényesítési erők uralkodnak. A környezeti és társadalmi fenntarthatósági célok meglátása szerint azért nem kapnak mikroszinten kiemelt figyelmet a gazdasági önérdekekkel ellentétben, mert nem keletkeznek közvetlen költségek a negatív környezeti és társadalmi hatások indukálásáért. Ezzel is igazolva a kizöldülés és a társadalmi szolidaritás kapcsán hiányzó müködőképes ösztönzők problémáját. Annak érdekében, hogy hidat verjünk a mai fenntarthatatlan teherszállítási mintázat és egy környezetileg fenntartható globális szállítási rendszer között tátongó szakadékra komoly változásokra, változtatásokra van szükség. Létfontosságú lenne azonosítani azokat a tevékenységeket, amelyek fontos szerepet játszhatnak ezekben a változtatási folyamatokban (Santén, 2013).

Vrat (é.n.) még mélyebbre tekint, egészen az emberig: mentális és viselkedési tényezőkkel is magyarázza a konfliktusokat (érdek- és értékütközéseket) és a nem hatékony áruszállítási rendszerek problémáit.

1. Rendezetlenség, szervezetlenség: balesetek, korrupt cselekedetek, önérdekkövetés, rossz parkolási szokások, túlterhelés, gyorshajtás, bevételkiesés, gyújtogatás, durva viselkedés a szereplők részéről.

2. Hatékonyságbeli hiányosságok: nem összehangolt közlekedési lámpák, elidősödő és nem karbantartott jármüállomány, kátyúk, magas üzemanyagfogyasztás, alacsony kihasználtság, szükségtelen forgalmi akadályok, torlódás, a tömegközlekedési rendszerek nem megfelelő tervezése, nem megfelelö információáramlás. 
3. Önző emberi viselkedés: nem megfelelö viselkedés az utakon, a közösségi közlekedés igénybevételének mellözése, szabálykövetés hiánya.

4. Közöny: vevöorientáció hiánya, közöny a fentebb említett hiányosságokkal szemben, közlekedési szabályon be nem tartása (motivációs és a kontrollmechanizmusok hiányosságok)

A problémákra és a kihívásokra formázott intelligens válaszok, és ezen válaszok megalkotásának a képessége lehet véleményem szerint az egyik meghatározó alapja a fenntarthatóságnak. Áttekintve az eddigi fejtegetéseket az alábbi sarokpontokat tartom relevánsnak a fenntartható áruszállítás vonatkozásában, illetve a fenntarthatóság szempontjából általában.

A rendszerszemlélet, az integrált/egymásba ágyazott struktúrák, a folyamatok elötérbe helyezése a korábbi statikus szemlélettel szemben (TBL). A rövid távú egyéni önérdekek és a hosszú távú közösségi vagy magasabb szintü érdekek ütközése, az ösztönzök szerepe, az elköteleződések és az attitüdök fontossága, az innovációk, a közösségi kultúra, a kontroll és a szabályzás szerepének hangsúlyozása. Ezek eddig nem nagyon jelentek meg expliciten a definíciókban. A következö fejezet a fenntartható teherszállítás meghatározásait ismerteti a szakirodalmi bázisra támaszkodva.

\section{A fenntarthatóság értelmezése az áruszállításban}

A fenntartható szállítás jelenlegi definíciói eltérhetnek egymástól tartalmukban és sok esetben pusztán egy vetületre koncentrálnak: (1) környezeti (zöld szállítás), (2) társadalmi (inkluzív szállítás) vagy (3) a gazdasági dimenzió (hatékony és versenyképes szállítás). Általában elmondható, hogy a fenntartható áruszállítás azt a célt tüzi ki, hogy kiegyensúlyozza, összehangolja a gazdasági, társadalmi és környezeti dimenziókat olyan integrált* módon, hogy mindez biztosítsa a pozitív szinergiák kialakulását a szektorban, a rendszer funkcióinak támogatását, kiegészítését és a koherencia megvalósítását (Sehlleier et al., 2017; United Nations, 2015). (*az integráltság itt a fenntarthatósági vetületek horizontális irányú közös metszetképzési lehetőségeire utal)

A fenntartható áruszállítás rendszere - a teljesség igénye nélkül - az alábbi olyan jellemzökkel írható le, amelyek képesek biztosítani azt, hogy a szállítás biztonságos, társadalmilag inkluzív, hozzáférhető, megbízható, megfizethetö, üzemanyaghatékony, környezetbarát, alacsony káros anyag kibocsátású és ellenáll a sokkoknak, a zavaroknak, beleértve azokat, amelyeket a klímaváltozás és a természeti katasztrófák idéznek elő (United Nations, 2015). Az ENSZ egy másik dokumentuma ennél is részletesebben taglalja a kereskedelmet kiszolgáló logisztika funkcióinak hozzájárulását a Fenntartható Fejlődési Célokhoz (UN SDGs) (United Nations, 2017).

A fenntarthatóság általános definíciója szerint már ismert, hogy az ökológiai megfontolásokat kombinálni kell a gazdasági fejlődéssel és a társadalmi felelősségvállalással. A logisztikában az egyik legfontosabb célkitüzés ugyanakkor a vállalatok hatékonyságának és gazdasági teljesítményének az elősegítése. Így azon elképzelések megvalósítása, amelyek hozzájárulnak más társadalmi célokban 
történő változásokhoz akár a környezeti, akár a társadalmi felelösségvállalás kapcsán, igen csak problémások, hacsak a rövid távú gazdasági érdekek kielégítése nem történik meg párhuzamosan (Santén, 2013 idézi Norman-MacDonald, 2004; Vachon-Klassen, 2008).

Manapság a fenntarthatóság koncepciója már megjelent a logisztikával foglalkozó szakirodalom érdeklődési fókuszában is, még akkor is, ha mindez mármint a fogalom - nem jól körülhatárolt és tartalmilag lehatárolt. A definíciók legtöbb részében, amikor a fenntartható logisztikáról van szó, akkor alapvetően a környezet tárgyalása kerül a középpontba, ilyen esetekben „zöld logisztikáról” beszélhetünk. De mit is érthetünk alatta? Erre számos meghatározást kínál a szakirodalom:

(1) A zöld logisztika egy környezetbarát és hatékony szállítási és elosztási rendszer (Rodrigue et al., 2001). (2) A zöld logisztika célja, hogy gazdasági hasznokat realizáljon bizonyos termékek kapcsán és egyszerre különös figyelmet fordítson az erőforrások megóvásának és a természetvédelemnek (Ping, 2009). (3) A zöld logisztika arról szól, hogy egy fenntarthatóbb egyensúlyt teremtsünk a gazdaság, a környezet és a társadalmi célkitüzések között (McKinnon-Piecyk, 2010).

Ha a „fenntarthatóság” kifejezést elemezzük a vonatkozó fejtegetésekben, akkor különböző jelentéseket és értelmezéseket találhatunk arra, hogy mi is a fenntartható logisztika valójában (Santén, 2013 idézi Carter-Rogers, 2008).

Összességében a fenntarthatóság koncepciójának adaptációja vállalati operatív müködésre nagyon bizonytalan és homályos. Norman és MacDonald (2004) azonban kritikusan állt a korábbi, hagyományos megközelítéshez és arra a következtetésre jutottak, hogy az nem más, mint egy „jó, öreg egytényezös plusz a homályos elkötelezödéssel járó társadalmi és környezeti vonatkozások elegye”. Norman és MacDonald által felállított érvek java része a koncepcióban lévő bizonytalanságokat érinti, illetve azokat a nehézségeket, amelyek a mérésre, értékelésre és a társadalmi felelösségvállalások összehasonlítására, valamint a környezeti kérdésekre vonatkoznak a szektoron belül és a szektorok között (Norman-MacDonald, 2004). A bonyolult kölcsönhatások a különbözö fenntarthatósági koncepciók szempontjai között igencsak megnehezítik a részletes, mindenre kiterjedő definíció megalkotását és annak alkalmazhatóságát. A fenntarthatóság meghatározásai gyakran olyan szerteágazóak, hogy nehéz azokat a vállalati múködési környezetre értelmezni, illetve a gyakorlatba átültetni (Bowen et al., 2001; Venkataraman, 2009).

A jövő üzleti versenyképességének eléréséhez a cégeknek nagyon fontos lesz, hogy hosszabb időtávban gondolkodjanak, valamint az ökológiai és társadalmi aspektusokat sokkal jobban elönyben részesítsék, így megvalósítva a magasabb színvonalú rendszerszemléletet (Holmberg-Robért, 2000). Globális szinten a társadalmi fejlődés radikális változásokat idéz elő a komplex ökoszisztéma müködési környezetében. Mindezt jól illusztrálja a megváltozott klíma, a biodiverzitás csökkenése, a Föld kincseinek túlzott elhasználása, elfogyasztása, a túlnépesedés és a szennyezésböl fakadó egészségügyi hatások (globális szintü mintázatok). Az ilyen jellegü érvelés összhangban áll a fenntarthatóság erős 
értelmezésével: megkövetelve azt, hogy a szigorúbb környezeti kontrollon legyen nagyobb hangsúly, mintsem a gazdasági és társadalmi következményeken. Ezt a gondolkodásmódot szélesebb körben is alkalmazni kellene annak érdekében, hogy megfékezze a globális környezeti problémákat (McKinnon, 2010).

Az elöző bekezdés legfontosabb kulcsszavait és gondolatait összeszedve az a meggyöződésem kap megerösítést, hogy a fenntarthatóság értelmezése és „menedzselése” kizárólag dinamikusan változó, nemlineáris rendszerekben gondolkodva képzelhetö el (hosszabb idôtávú szemlélet, rendszerszemlélet, globális szintü klimaváltozás, biodiverzitás csökkenése - mint makroszintü jelenségek, kontrollmechanizmusok szükségszerüsége).

A teherszállítási logisztika kapcsán sincs ez másként. A globális logisztikai rendszerben is megfigyelhetőek a szereplök közötti struktúrák, a hierarchikus rétegződések és a rendszerdinamikai folyamatok. A globális szintü problémák az egyes szereplök mikroszinten megvalósuló önérdekkövető cselekedeteiböl, reakcioiból és interakcióiból alakulnak ki a komplex rendszerek dinamikai jellemzőik révén. Nem hagyható figyelmen kívül azonban a rendszer, illetve a részrendszerek strukturális felépítése sem, és az ehhez kapcsolható, a fenntarthatóságot, a kreatív-innovatív rugalmas adaptációt és a rezilienciát, stressztürő képességet elősegítő tulajdonságok.

$\mathrm{Az}$ érintettek beazonosítása és csoportosítása számos helyen megjelenik (pl.: CEPA, 2014; Santén, 2013; Sehlleier et al., 2017). Előbbinél a funkciók ellátása ezen belül élesen koncentrálva a konkrét szállítási feladatokra -, a kereslet-kínálat szereplöi és a tágabb müködési kör szférái kapnak hangsúlyt. Ezen belül említést kapnak a szállítási kapacitások tulajdonosai, hajóstársaságok, légiközlekedés, közúti szállítási ágazat, vasúti szállítás, raktározás, kikötők, technológiai fejlesztők és innovátorok, üzleti vezetök, tökések, kormányzat, munkaerő, légkör (légifolyosó), érintett közösségek, ökoszisztémák.

Ez eddigiek kapcsán látható volt, hogy a fenntartható makroszintű teherszállítási logisztika attribútumait már többé-kevésbé ismerjük, legalábbis van némi fogalmunk, hogy milyen irányban kellene elmozdulnunk a fenntarthatóság megvalósításának érdekében. Ne felejtsük el, hogy pusztán ennek a rendszernek a fenntarthatósága nem garantálja a teljes globális fenntarthatóságot. A rendelkezésre álló definíciók logikáját követve a szakirodalomban megjelennek a megoldási javaslatok, illetve a hozzájuk kapcsolódó szük keresztmetszetek és a kockázatok is. Ezek ismertetése a következő fejezetben történik meg.

\section{A teherszállítási logisztika fenntarthatóságának megvalósítási kockázatai és nehézségei}

A szakirodalomban fellelhető javaslatok túlnyomó része a hagyományos fenntarthatósági megközelítéshez társul és nem veszi figyelembe a nemlineáris rendszertulajdonságokat, amelyek meghatározzák a valós folyamatokat. Ezek áttekintése ugyanakkor hasznos is lehet, hiszen ötleteket adhat az új megközelítésbeli adaptációikhoz. Számos javaslat igencsak közhelyesnek és tartalom nélkülinek 
tünik, illetve egyedüli megvalósításuk garantáltan nem járul hozzá a valós fenntarthatósághoz.

A hagyományos megközelítéshez sorolhatóak (CEPA, 2014; University of Leeds-European Parliament, 2010; Vrat, é.n.):

- megújuló energia használata a lokális zéró vagy zéró közeli berendezések, jármüvek használata kapcsán

- a tiszta levegö és az egészséges közösségek támogatása

- hosszabb távon radikálisan eltérö áruszállítási módok is elérhetővé válnak, amelyek kifejlesztése, illetve gyakorlati felhasználásuk térnyerése jelentős költségcsökkenést jelenthet az alkalmazásuk kapcsán

- tiszta energia használata (napenergia, árapály-energia, szélenergia)

- zöld ellátási láncok tervezésénél figyelembe kell venni (és felülvizsgálni) az ökológia lábnyomot (környezeti terhelés), illetve a karbon kvóta kereskedelem ösztönzési mechanizmusait fenntartani

- az áruszállításban legyenek felhasználva és jól kihasználva a megújuló energiaforrások

- csőszállítás lehetőségeinek további kihasználása

- futószalagok és kötélpályák hegyes vidékeken, valamint a gravitáció kihasználása

- az áru mozgatása, az áruszállítás legyen hatékonyabb. Az ERTRAC (2011), az Európai Közúti Közlekedési Kutatási Tanácsadó Testület (European Road Transport Research Advisory Council) olvasatában a hatékonyság három fö pilléren nyugszik. I. Károsanyag-kibocsátás visszaszorítása (ezen belül: a városi közlekedés energiahatékonysága, hosszú távú szállítás energiahatékonysága és a megújuló energiaforrások részaránya). II. Megbízhatóság (szállítási idők megbízhatósága, városi hozzáférhetőség). III. Biztonság (a súlyos közlekedési balesetek számának csökkentése, a rakományveszteség csökkentése - lopáskárok és egyéb károk visszanyesése)

- a logisztikai iparág versenyképességének fokozása

- kapacitások kihasználásának optimalizálása azáltal, hogy mindkét irányban (oda-vissza) kihasznált legyen a szállítási kapacitás

- a konténeres szállítás továbbfejlesztése a háztól házig (gyártótól házig) szállításban

- a csomagolás minőségének javítása annak érdekében, hogy csökkentsük az anyagmozgatás és a raktározás során keletkező hulladékot. Csomagméretek standardizálása a kapacitások maximális kihasználásának érdekében

- növelni a tehervonatok sebességét, biztonságát és közbiztonságát

- teherautók és vagonok megosztása, bérbeadása a magánszektor részére, hogy a kihasználatlan jármüveket, gördülö állományt hadra fogják

- nagysebességü vasútvonalak építése a fuvarozási idö csökkentésére, természetesen károsanyag-kibocsátás szempontjából fenntartható módon. Ez még ma gazdaságilag nem életképes.

- diesel vontatás visszaszorítása 
- vasúti szállítás részarányának növelése jobb müködési hatékonyság mellett és eredményes árképzéssel

- romlandó, humanitárius vagy sürgősségi áruszállításra legyen eredményes és megfizethető légi szállítási rendszer

A rendszerszemlélethez, a nemlineáris aspektusokhoz kapcsolódóak (CEPA, 2014; University of Leeds-European Parliament, 2010; Vrat, é.n.):

- a résztvevőket, a folyamatokat és a technológiákat integrált módon kell koordinálni (a nemlineáris és egymásba ágyazott rendszereknek megfelelöen)

- továbbra is fenn kell tartani a jelentős kutatási-fejlesztési beruházásokat a technológia terén (az intelligens alkalmazkodás elômozdításának alapjaként értelmezhetö, illetve a rendszerben aktívan résztvevö entitások képessé tételét segítheti elö)

- új ösztönzők bevezetése a viselkedési mintázatok megváltoztatására, mint például a közlekedési módozatok közötti váltások elösegítése az ármechanizmusok révén (a jotékony rendszerdinamikai folyamatok beindításához szükségesen)

- infokommunikációs technológiák fokozott használata az intelligens szállítási rendszerek kidolgozásának érdekében; az információáramlás felgyorsítása; az emberi hibák kiküszöbölése; zárt láncú videós megfigyelő rendszerek telepítése a korrupció és a kisebb lopások visszaszorítására és a biztonság előmozdításához (a lokális, mikroszintũ helyszíneken a kontrollmechanizmusok elömozdítását jelenti az utóbbi pár gondolat)

- célzott közösségi elosztási rendszer informatikai támogatottsággal

- az infokommunikációs technológiák és a számítástechnikai fejlesztések hozzájárulhatnak a fenntartható áruszállításhoz az ellátási láncokban ( $a$ minöségi információk elérésének lehetösége az entrópiát csökkentheti a rendszerben - a fenntarthatóság tulajdonképp nem más mint az entrópia elleni folytonos ,küzdelem")

- nemzeti és globális rendszerekhez kapcsolódjon a logisztika alrendszer (integráltság, tovagyürüzö hatások figyelembevétele)

- megbizható, tartható sebesség és fokozott kapacitás biztosítása (utóbbi a hálózatok áteresztõ képességének javítását célozza meg; a heterogén szereplök, elemek összekötése a rendszer rugalmasságát és minél hatékonyabb teljesítőképességét szolgálhatja potenciálisan)

A fenntarthatóság megvalósításának, illetve a logisztikai rendszer teherszállítási alrendszerének fenntartható pályára való állításának korlátai, kockázatai sem hagyhatóak figyelmen kívül. A kockázatok természetesen számtalan nézőpontból megfogalmazhatóak és csoportosíthatóak. Az Európai Környezetvédelmi Ügynökség (EEA) észrevételei azonban azért érdekesek és relevánsak, mert a nemlineáris megközelítésre is alkalmazhatóak (European Environmental Agency, 2016).

Az Ügynökség a szereplök rövid távú (profit, haszonmaximalizálo) érdekeinek általános felértékelődésére számít a hosszú távú, kollektív, fenntarthatósági érdekek 
ellenében. Azt látják, hogy a kontroll-mechanizmusok, amelyek a visszaélések (a fenntarthatóság szempontjából kívánatos folyamatoknak ellenében történő cselekmények) visszaszorítására lennének hivatottak nem eredményesek és korlátozottan müködnek. Fontos kérdésként azonosítják be, hogy miként oldható meg az (fenntarthatóságot elősegítő) innováció ösztönzése és ennek a masszív finanszírozási igényének a megvalósítása egy olyan kompetitív környezetben, ahol alapvetően a költségelőnyök dominálnak, nem is beszélve arról, hogy a vállalati szintü „kizöldülés” hogyan konvertálható versenyelőnnyé. Az ármechanizmusok dinamikus alakulása szintén ide sorolható (energia, üzemanyag, megtérülés, költségelőnyök stb.). Komoly nehézséget jelent az, hogy a hatásmechanizmusok (makroszintű mintázatok okainak) feltárása nehézkes vagy lehetetlen - a fenntarthatóságot meghatározó tényezők interdependenciáinak azonosítása, illetve azok dinamikájának a megragadása kihívásokkal teli.

Hasznos lehetne tehát egy olyan értelmezési keretrendszert kidolgozni, amelyben a hagyományos és a dinamikus fenntarthatósági kritériumokat ötvözve megtaláljuk. Az elképzelésem lényegét az alábbi, 1. számú ábra képezi le. Itt mind a horizontális, mind a vertikális integráltság tetten érhető.

\section{1. ábra: A fenntarthatóság integrált szemlélete a nemlineáris rendszerekben}

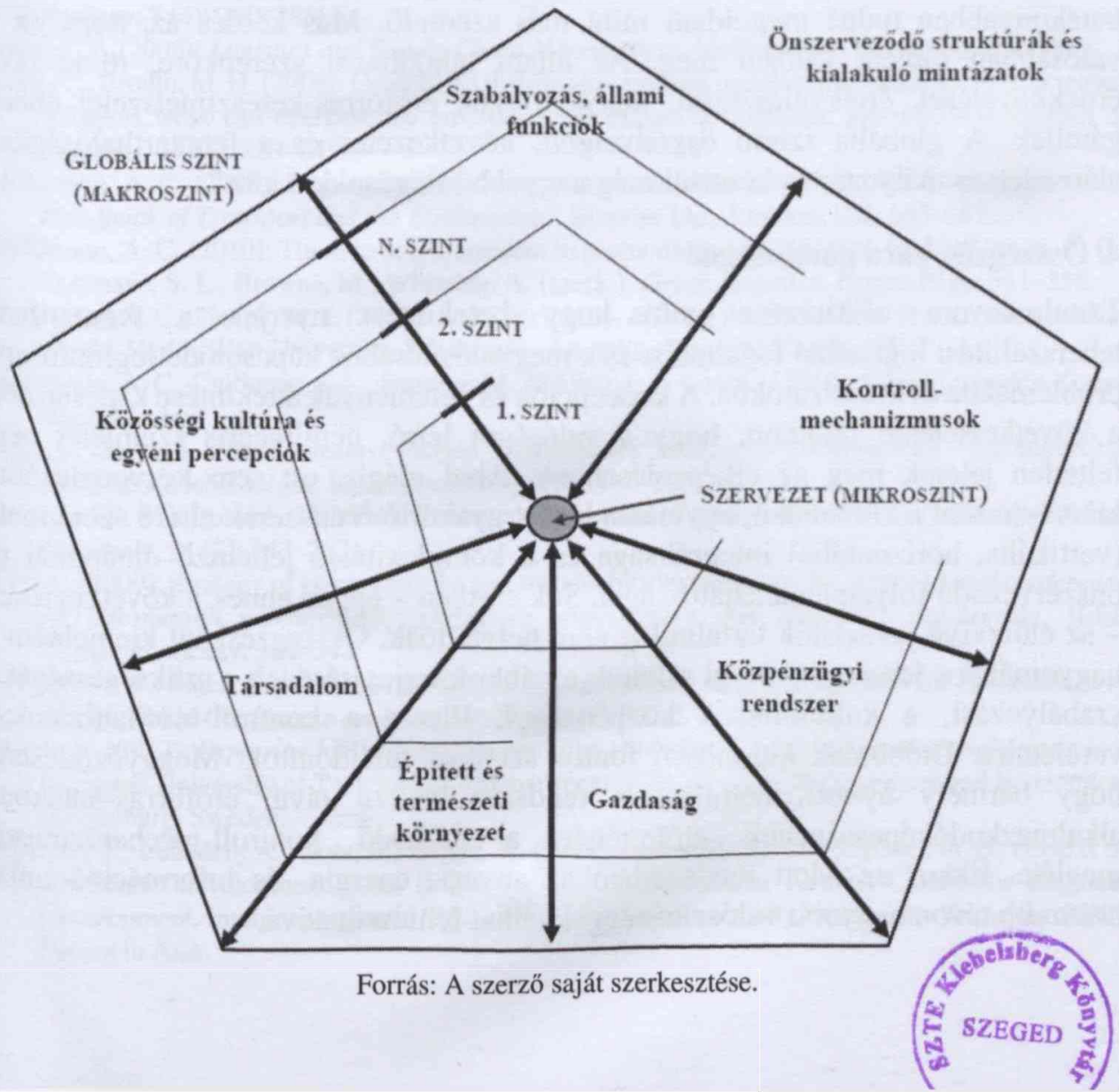


Az ábrában látható nyilak iránya egyrészt utal a vizsgált rendszerben kialakuló folyamatok alapvető fejlődési, önszerveződési direkcióira. Ennek megfelelöen az alulról szerveződő rendszerdinamikai folyamatok a magasabb szinteken alakítanak ki mintázatokat. Másrészt, az ellentétes irány a visszacsatolási vagy tanulási folyamatokra utal. A különböző szintek $(1 \ldots n)$ földrajzi és funkcionális lehatárolásban is értelmezhetőek. Az integrált szemlélet mögött természetesen az egyes szereplők közötti hálózati struktúrák húzódnak meg. Ha a teherszállítást vizsgáljuk, és annak alárendelve tekintünk az ábrára, akkor is könnyen értelmezhetővé és indokolttá válnak a fenntarthatósági pillérek és azok kiterjesztése. A teherszállítási logisztikának - ahogy az a szakirodalomban is látható volt meghatározó összefonódásai vannak az ábrán lehatárolt vetületekkel (részletesebben: McKinnon et al., 2010; Sehlleier et al., 2017). Ugyanakkor a közpénzügyi vonatkozások, a szabályozás, illetve a tevékenységeket és a folyamatokat kontrolláló funkciók alig kerültek részletesebb tárgyalásra. Utóbbi kettő összehangolása, „szimbiózisa” és professzionális müködése, múködtetése különösen fontos lenne a fenntartható teherszállítási logisztika megvalósításában. A szabályozás kialakítása, finomhangolása és a szabályok betartatása az államnak lenne a feladata, hiszen kényszerítő hatalma és a releváns információkra való rálátásának köszönhetően ezt a tevékenységét eredményesen és sokkal hatékonyabban tudná megoldani mint más szereplő. Más kérdés az, hogy ez a valóságban miként valósul meg. Az állam tulajdonosi szerepköre, rövid távú érdekkövetései, értékválasztásai, illetve a szük erőforrás-keresztmetszetei ebben gátolják. A globális szintü összehangolt, következetes és a fenntarthatóságnak alárendelt szabályozás és kontroll még nagyobb kihívásokkal küzd.

\section{4. Összegzés, záró gondolatok}

Tanulmányom célkitüzése volt, hogy betekintést nyerjek a fenntartható teherszállítási logisztika fogalmába és a megvalósításához kapcsolódó legfontosabb problémákba és kockázatokba. A koncepciók és vélemények áttekintése kapcsán arra a következtetésre jutottam, hogy a valóságot leíró, nemlineáris szemlélet nem feltétlen jelenik meg az elképzelésekben. Ahol mégis, ott sem körvonalazódik kristálytisztán a különböző, egymásra hatást gyakorló rendszerek eltérö szempontú (vertikális, horizontális) integráltsága és a komplexitásra jellemzö dinamikai és önszerveződő folyamatok sajátosságai. Sok esetben - éppen ennek a következtében - az elörevivő javaslatok tartalmilag nem helytállóak. Összegzésként kiemelném a hagyományos fenntarthatósági pillérek további kiterjesztésének a szükségességét a szabályozási, a kulturális, a közpénzügyi, illetve a kontroll-mechanizmusok vetületeire. Utóbbinak különösen fontos szerepet tulajdonítok. Meggyőződésem, hogy bármely nyitott, nemlineáris rendszer hosszú távú, erőforrás-hatékony alkalmazkodóképességének elöfeltétele a müködő kontroll-mechanizmusok megléte. Ekkor az adott rendszerben az anyag-, energia- és információramlás hosszabb távon nagyobb valószínüséggel válhat fenntarthatóvá. 


\section{Irodalomjegyzék}

Bowen, F. E., Cousins, P. D., Lamming, R. C., Faruk, A. (2001): Horses for courses: Explaining the gap between the theory and practice of green supply. Greener Management International, 35 (3): 41-60.

Carter, C. R., Rogers, D. S. (2008): A framework of sustainable supply chain management: Moving toward new theory. International Joumal of Physical Distribution and Logistics Management, 38 (5): $360-387$.

CEPA (2014): Sustainable freight transport. California Environmental Protection Agency - Air Resources Board.

ERTRAC (2011): Sustainable Freight System for Europe Green, Safe and Efficient Corridors European Roadmap. European Road Transport Research Advisory Council - Working Group on Long Distance Freight Transport.

European Commission (2015): Smart and sustainable logistics for a competitive Europe. Transport Research and Innovation Portal (TRIP) consortium for the European Commission's DirectorateGeneral for Mobility and Transport (DG MOVE). doi: 10.2832/90452

European Environmental Agency (2016): Transitions towards a more sustainable mobility system TERM 2016: Transport indicators tracking progress towards environmental targets in Europe. EEA Report No. 34/2016. doi: 10.2800/895670

Golicic, S. L., Boerstler, C. N., Ellram, L. M. (2010): „Greening” Transportation in the Supply Chain. MIT Sloan Management Review, 51 (2): 46-55.

Holmberg, J., Robért, K. H. (2000): Backcasting from non-overlapping sustainability principles - a framework for strategic planning. International Journal of Sustainable Development and World Ecology, 7 (4): 280-285.

Jonsson, P. (2008): Logistics and Supply Chain Management. McGraw-Hill Education, Berkshire.

Kohn, C., Brodin, M. H. (2008): Centralised distribution systems and the environment: How increased transport work can decrease the environmental impact of logistics. International Journal of Logistics, 11 (3): 229-245.

McKinnon, A. C. (2003): Logistics and the environment. In: Hensher, D. A., Button, K. J. (szerk.): Handbook of Transport and the Environment. Elsevier Ltd., London, UK, 665-687.

McKinnon, A. C. (2010): The role of government in promoting green logistics. In: McKinnon, A. C., Cullinane, S. L., Browne, M., Whiteing, A. (szerk.): Green Logistics. Kogan Page, 341-358.

McKinnon, A. C., Piecyk, M. I. (2010): Logistics 2050-Moving freight by road in a very low carbon World. Heriot-Watt University, Edinburgh - Logistics Research Centre, UK.

McKinnon, A. C., Cullinane, S. L., Browne, M., Whiteing, A. (szerk.) (2010): Green Logistics. Kogan Page, London.

Nagy S., Gulyás L. (2015): Számvevöszéki értékteremtés „turbulens” környezetben - a komplexitás kezelésének lehetőségei. Vezetéstudomány, 56 (7): 1-13.

Norman, W., MacDonald, C. (2004): Getting to the bottom of „Triple Bottom Line”. Business Ethics Quarterly, 14 (2): 243-262.

Ping. L. (2009): Strategy of green logistics and sustainable development. In: International conference on information management, innovation management and industrial engineering. IEEE Computer society, 339-342.

Rodrigue, J. P., Slack, B., Comtois, C. (2001): The paradoxes of green logistics. In: Proceedings of the 9th World Conference on Transport Research, Seoul, South-Korea.

Santén, V. (2013): Exploring logistics actions enabling environmentally sustainable freight transport. Chalmers University of Technology - Department of Technology Management and Economics, Gothenburg, Sweden.

Sehlleier, F., Imboden, A., Gota, S., Hagge, K. (2017): Green freight and logistics in the context of sustainable development goals (SDGs) - Final draft. United Nations Centre for Regional Development, Intergovernmental Tenth Regional Environmentally Sustainable Transport (EST) Forum in Asia. 
United Nations (2015): Sustainable freight transport systems: Opportunities for developing countries. United Nations Conference on Trade and Development. UNCTAD Secretariat Trade and Development Board.

United Nations (2017): Trade logistics and the 2030 Agenda for Sustainable Development. United Nations Conference on Trade and Development. UNCTAD Secretariat Trade and Development Board.

University of Leeds, European Parliament (2010): The future of sustainable freight transport and logistics - Workshop „The future of transport. Institute for Transport Studies - European Parliament's Committee on Transport and Tourism.

Vachon, S., Klassen, R. D. (2006): Extending green practices across the supply chain: The impact of upstream and downstream integration. International Journal of Operations and Production Management, 26 (7): 795-821.

Vachon, S., Klassen, R. D. (2008): Environmental management and manufacturing performance: The role of collaboration in the supply chain. International Joumal of Production Economics, 111 (2): 299-315.

Venkataraman, B. (2009): Education for Sustainable Development. Environment: Science and Polic) for Sustainable Development, 51 (2): 8-10.

Vrat, P. (é.n.): Sustainable freight transportation and logistics. ITM University Gurgaon.

Wandel, S., Ruijgrok, C., Nemoto, T. (1992): Relationships among shifts in logistics, transport, traffic and informatics. In: Huge, M., Storhagen, N. (szerk.): Logistiska Framsteg - Nordiska forskningsperspektiv på logistik och materialadministration, Studentlitteratur, Lund, 96-136. 